\title{
Relationships of Marketing, Customer Satisfaction and Customer Loyalty - A Case Of Vietnamese Dairy Retail Stores in Ho Chi Minh City, Vietnam
}

\author{
Trung Minh LAM ${ }^{1}$, Bach Tuan $\mathrm{LE}^{2}$, Tuan Hoang Anh DINH ${ }^{3}$, Hieu Minh VU \\ \{trung.lm@vlu.edu.vn ${ }^{1}$, bachstep1008@gmail.com² ${ }^{2}$ dhatuan@upt.edu.vn ${ }^{3}$, hieu.vm@vlu.edu.vn ${ }^{4}$ \\ Faculty of Business Administration, Van Lang University, Vietnam ${ }^{1,}$ Foreign Trade University, Ho \\ Chi Minh City Campus, Vietnam ${ }^{2}$. Department of Post Graduate - Phan Thiet University, Vietnam ${ }^{3}$, \\ Faculty of Business Administration, Van Lang University, Vietnam ${ }^{4}$
}

\begin{abstract}
With the current high market competition, all businesses must have a suitable approaches and strategies to develop more and more customers and achieve their customer satisfaction and loyalty. This work aspires to inspect the relationships of the marketing, customer satisfaction and customer loyalty in Vietnamese dairy retail stores in Ho Chi Minh City, Vietnam. The study employs to methods of qualitative and quantitative. The qualitative technique is gone with the related literature and theories, consultations with 6 academic researchers, 27 business owners, and 15 managers, group discussions and 3 in-depths planned interviews with 30 random customers. The quantitative tool is done with 200 surveyed questionnaires with the customers in milk product retail stores in Ho Chi Minh city. The findings show 4 important factors affecting customer satisfaction: Product, Price, Promotion, Place (Distribution channel) and 2 crucial other factors: Satisfaction and reference group have linear relationships with customer loyalty. The findings are expected to add to the accessible literature to both theoretical and managerial approaches for a superior understanding of the activities of the marketing mix, customer satisfaction, and customer loyalty, particularly in the research trade setting..
\end{abstract}

Keywords: Customer loyalty, Customer satisfaction, Dairy retail stores, Ho Chi Minh city, Marketing (relationship marketing).

\section{Introduction}

At present, many new entrants providing similar products/ services and product substitutes are available in the market and the industry (Alden, 2012; Purnamasari, 2013). Besides, as known, the world has suffered from the Covid-19 pandemic and it causes business markets to become more and more competitive and constant change. Businesses need to compete and search for suitable approaches to strengthen their competitive advantages to survive in the industry.

Quelch and Jocz (2009) and Wixcey (2014) depict that customers get smarter, more selective, more demanding, more sensitive to price, more familiar with products/ services but they are less loyal to businesses. More of that, Kuusik (2007) affirms customers own relatively limited time and they must find out the highest value for themselves. Also, the long-term success of the businesses is upon various determinants, not only for the optimized product 
price and the qualities as well (Kuusik, 2007). According to Parekh (2019) and Solnet and Kandampully (2008), customers are the cornerstone and the main determinant of the businesses' existence. In this 21st century, customers are of major significance for any business, specially in the framework of retail sales. Also, Nwakanma, Jackson and Burkhalter (2007) confirm that customers must be at the center of a businesses' operations and businesses must have the right strategy to serve better customers' needs. Businesses should make their achievement and development on a enduring customer relationship (Kuusik, 2007) and both of the satisfaction and the loyalty of the customers are always seen as the goal of the marketing activities (Nwakanma, Jackson \& Burkhalter, 2007). Besides, Kaur and Sharma (2009) point out customer satisfaction are the crucial element of the strategic decision process in various marketing activities. Many findings of the recent studies show customer satisfaction and loyalty own an extremely crucial role in the businesses' success and development (Dubrovski, 2001; Nwakanma, Jackson \& Burkhalter, 2007; Kaur \& Sharma, 2009). Customer satisfaction is seen as a prerequisite or sufficient condition for customer loyalty, and a tool to create the businesses' profits (Hill, Roche, \& Allen, 2007).

As seen, the overall business strategy must be towards to the customers significantly concentrating on the generation of customer satisfaction and loyalty throughout the strong and good relationships with customers, and as such, marketing activities are placed as one of the most crucial issues and a useful weapon to maintain and develop customer satisfaction and loyalty for businesses. Keeping a positive interaction with consmers is the key to success in business operations (Lund, 2021). Ndubisi (2007) states that customer loyalty will be increased by increasing the relationship marketing concentrating on the customer.

As an emerging country, due to the extensive economic integration and influence of the COVID-19 pandemic in the world and Vietnam, growth reduced but remained in optimistic territory in 2020 with $1.6 \%$. As per the rationalized IMF forecasts from January 2021, GDP development in Vietnam is probable to bounce back to $6.7 \%$ this year and $7.4 \%$ in 2022 (Chung, 2021). As for Vietnam's dairy industry, according to the Vietnam Dairy Association report in 2019, there are over 70 dairy producers and traders with more than 300 domestic and foreign brands. In terms of the revenues, the dairy industry has been making a positive contribution to the country's economy by its rapid growth, the revenues of the following year are always higher than the previous year at the average from $15-17 \%$ per annual. As known, milk is an essential consumer commodity, and household require for dairy products is not mainly affected by Covid-19. The demand for dairy products in the Vietnamese market is growing at a high rate, dairy enterprises have had many opportunities to approach market development and pursue different product marketing strategies. In particular, it reduced by only $4 \%$ in rate while Fast Moving Consumer Goods (FMCG) consumption development reduced by $7.3 \%$. At present, the milk sector accounts for $12 \%$ of total FMCG sales in Vietnam, which is identical to that in 2019 (Chung, 2021). One of the marketing activities done to meet the demand requirements of the customers is to develop the retail stores (Hang, 2019, Nguyet, 2020) because the current big challenges and competition in the dairy industry. As a result, businesses must create outstanding customer relationships to develop customer satisfaction which leads to their customer loyalty and gain the business targets and profits consistently. However, in marketing activities, businesses must pay attention to influencers (called reference groups) rather than the entire target market, because influencers can alter customer behavior. The reference group is an important factor influencing users' purchases by its informative influence and normative influence because, in different purchases, customers gain different product information, experience, and attitudes. Customer satisfaction with businesses' products or services will lead customers to willingly recommend to the publicity 
positively and to their relatives (Brunner, Stöcklin \& Opwis 2008.) Customer satisfaction will create and lead to customer loyalty due to their good experience with businesses' products or services. Currently, many works conversing the relationship between client fulfillment and reliability are available with different results.

Therefore, this study is to find the consequence of marketing mix comprising product, price, promotion, and place on loyalty through the arbitrating role of customer pleasure of the Vietnamese Dairy retail outlets in Ho Chi Minh city. The findings are expected to contribute to the accessible literature to both theoretical and managerial approaches for a enhanced understanding of the activities of the marketing mix, customer satisfaction, and customer loyalty, mainly in the research industry setting.

\section{Literature Review}

\section{Concepts of Customer satisfaction}

In the marketing discipline, the word "satisfaction" is significantly relative to customer needs and desires. Oliver (1997) has determined customer satisfaction as: "... Satisfaction is the response to consumer performance. It is a judgment that a product or service provided (or is being provided) has some degree of attraction to customers ..." (Oliver, 1997). Additionally, Hill, Roche and Allen (2007) state customer satisfaction is seen as "the feeling that the customer has about the degree of their experience with the organization that has met their needs". Also, Kotler and Keller (2006) affirm satisfaction is the emotional or emotional state gaining from perception and expectation comparison of a product/service they use. Customer satisfaction becomes a crucial and key goal in the enhancement of product/service quality, loyalty maintenance, and improvement the business competitiveness (Khan \& Fasih, 2014). It is a vital determinant to impress clients to keep the accomplishment of businesses in the long run (Zeithaml, Berry \& Parasuraman, 1996). Besides, Barnes (2003) states customer satisfaction is the reaction to the need fulfillment, and Kotler (2005) points out that customer fulfillment is the point of one's after comparing the apparent performance with his/her prospect.

\section{Understanding of customer loyalty}

Customer loyalty is placed as the central to marketing discipline (Toufaily, Ricard \& Perrien, 2013). From a practitioner's perception, customer loyalty is one of the main substantial properties of the businesses. In the literature, various definitions of loyalty are existing. Leverin and Liljander (2006) define reliability as a active commitment to re-buy or re-subscribe products/services that have been constantly chosen in the future. The term "loyalty" can be known as something that customers express to a certain brand, product, service and/or activity (Balbanis, Reynolds \& Simintiras, 2006) which is comprising three different elements (Balbanis, Reynolds \& Simintiras, 2006) as behavioral, attitudinal, and situational loyalty. Behavioral loyalty means the business products will be continued to purchase when finding their usage benefit (Zeithaml, 2000). Attitudinal loyalty is the customers' belongingness feeling towards a product or brand (Zeithaml, 2000) or the constant relationship between a customer and a brand which are strongly influenced by family and friends (Mascarenhas, Kesavan \& Bernacchi, 2006). And for situational loyalty, this is the loyalty type depending on the relationship to the brand and determined by the customers' purchasing and shopping status. Three of them are crucial, even though both types of 
behavioral and attitudinal loyalty are more emphasized when market share and long-term relationships are being developed.

Customer loyalty owns a vital role in the customer strategy of all businesses (Keiningham et al., 2007). How to enhance customer loyalty has always become the key research topic among managers, consultants, and academicians (Keiningham et al., 2007). Also, in the existing theory, there are many extensive models as Macintosh and Lockshin's model (1997), models of Flavian, Martinez and Polo (2001), Srinivasan, Anderson and Ponnavolu (2002) and Allender and Richards (2012).

For the contribution of the customer loyalty to the business operation, customer loyalty is as a pivotal issue for enhancement of profitability and maintenance of the businesses' position in the market (Haghighi et al., 2012), achievement of a major competitive advantage (Aksu, 2006; Aksoy, 2013), retention of the long-term, equally helpful relations with clients (Pan, Sheng \& Xie, 2012); occupation of attachment and commitment toward businesses, willingness to pay more, expression of superior purchasing purposes and switching resistance (Evanschitzky et al., 2012).

Aspects of reference group

Consumer behaviour is heavily influenced by the reference community. As a result, a reference group is any person or group that is used as a point of contrast (reference) when establishing general or special values or behaving. In marketing terms, a reference group is a group of people who are used as a benchmark for making buying or consuming decisions. As stated above, attitudinal loyalty is the customers' belongingness feeling towards a product or brand (Zeithaml, 2000) or the constant relationship between a customer and a brand which are strongly influenced by family and friends (Mascarenhas, Kesavan \& Bernacchi, 2006). Completely, most people have groups in their lives and these groups influence each of product purchasing decision. In terms of the influence of reference groups on the consumption process, it is crucial to adjust the consumption process with reference groups (Turčínková and Moisidis, 2011). More of that, reference groups consisting of family, friends or colleagues have the strong and great influence to consumer behavior in purchase decision (Chaudhary, 2018) by their advice and input factor for purchasing decision (Heung, 2012; Hussain et al., 2012; Rena, 2013 and Handoko et al.,2017)

As for the definitions of reference groups, many of them are available in the theory. It is considered as a group which an individual references during the process of decision making, judgment, cognition, and behavior (Hawkins \& Mothersbaugh, 2013; Schiffman \& Wisenblit, 2015). In the study of Schiffman, Kanuk, \& Hansen (2012), reference group is a person or group serving as a point of comparison (or reference) for an individual in the formation of either general or specific values, attitudes or behaviour (Schiffman, Kanuk, \& Hansen, 2012). According to Kotler (2012), the reference group is a group influencing directly or indirectly on a person's attitude and behavior. According to Zia (2011), a reference group (preference group) is an individual or group of people that significantly affects someone. According to Dhurup et al. (2013), the reference group is defined as a person or group of people who significantly has the effect on an individual's behavior. Sumarwan (2011) affirms reference group has the close relation to the consumers' behavior in their purchasing decisions. This is agreed by Bearden and Michael (2011) that reference groups as family / friends / partner can strengthen consumers' desire to repurchase products. Mantasari (2013) affirms groups include friends, family, friendship groups, shopping groups, work groups, virtual groups or communities and celebrities and these groups differ in behavior depending on the age, geographical surroundings, level of education, social and marital status regarding purchasing 
behavior. Hawkins et al. (2007) and Hsiung et al. (2013) point out several reference groups have their influences in the form of informational, utilitarian, and value expression.

Armstrong and Kotler (2011) define Marketing as a set of steps delivering value which customer can remember, create a relationship with customers and deliver benefits to the organization. Besides, Kotler and Keller (2016) affirm marketing mix comprising of 4Ps as product, price, place, and promotion is the distribution and communication of the customer value to the market of which 4Ps (also called as marketing mix) are the controllable medium reflecting customer's satisfaction (Shankar \& Chin, 2011). Also, American Marketing Association - AMA in 2017 states "Marketing is the activity, set of institutions, and processes for creating, communicating, delivering, and exchanging offerings that have value for customers, clients, partners, and society at large" (AMA, 2017).

However, many marketing scholars have criticized the 4Ps of the marketing mix from different perspectives (Akroush, 2010) and many marketing models as 7Ps (product, price, place, promotion, people, process, and physical evidence) or Relational/ Relationship marketing have been developed and existed in the literature. Some scholars agree 4Ps marketing mix is traditional marketing, and others are modern marketing. In terms of the contribution of Marketing to the businesses, Bay, Petrizzi and Gill (2008) confirm marketing mix will make businesses increase the sales and profits level.

As stated by Smith (2020), the traditional marketing mix (4Ps Marketing) is concentrating on the whole addressable market and relationship marketing is targeting individual customers in the market. Moreover, in modern marketing, relationship marketing is seen as the cornerstone of modern marketing literature (Gronroos, 2004). The relationship marketing concept has emerged within the fields of service marketing and industrial marketing (Gronroos, 2004; Akroush, 2010). Relationship marketing is considered as an alternative model to replace the traditional marketing mix theory (transactional marketing). Relationship marketing aims to improve the acquisition and retention of profitable customers efficiently and effectively by selective initiation, development, and maintenance of the appropriate relationships with customers (Payne \& Frow, 2005; Osarenkhoe \& Bennani, 2007). relationship marketing is "to identify, establish, maintain and enhance relationships with customers and other stakeholders, at a profit, hence, the objectives of all other related parties are achieved; this is done by a mutual exchange and fulfillment of promises" Gronroos (2004). Relationship marketing encompasses skills of creating and building long-term relationships with customers (Gronroos, 2004, Payne \& Frow, 2005), enhancing and maintaining highquality relationships with customers (Roberts, Varki \& Brodie, 2003; Ventetis \& Ghauri, 2004); building and keeping detailed customers database (Payne \& Frow, 2005).

In addition, Kotler (2005) affirms relationship marketing is a procedure of generating, preserving, and reinforcing relationship that is full of worth with the clients and other believers. It is not for development of a short-term transaction but for creation of a long-term relationship with the clients which regularly exploit a equally helpful relationship with customers and other related stakeholders. This concept is also agreed by Wibowo (2006). He states that relationship marketing as a progression in which businesses develop a long-term agreement and relations with their existing clients or potential customers and cooperate for achievement of the established goals (Wibowo, 2006) by accepting the customers' needs, treating the customers as partners, meeting the customers' satisfaction, and providing quality products throughout the employees' commitment. The key relationship marketing goal is to enhance the customer satisfaction which directs to customer loyalty (Tjiptono, 2000). 


\section{Relations of marketing mix, customer satisfaction and customer loyalty}

Facing the highly competitive environment, the importance of the development of strong relationships with their customers has been recognized in all businesses (Morgan \& Rego, 2006). In most of the businesses' development, the supports of two extremely crucial factors customer satisfaction and customer loyalty are recognized (Caruana, 2002; Chigora \& Zvavahera, 2015) because both impact the profitability revenues of the businesses (Rosenberg \& Czepiel, 1984)

According to Nuseir and Madanat (2015), traditional Marketing (mix of 4Ps) is to face the environmental challenges seriously to achieve greater market share and is considered as a key contributor to develop and increase customer loyalty and customer satisfaction in terms of businesses' products (Nuseir \& Madanat, 2015). In the contrast, modern/ relationship marketing is a business philosophy and a strategic orientation concentrating on the development of a good long-term relationship among stakeholders, suppliers, and customers of which will strengthen customer loyalty (Payne, David \& Christopher, 2005). Because customer satisfaction will establish and raise customer loyalty being the key capital to achieve and to survive in the competition and customers are willing to recommend the businesses to their relativeness (Chigora \& Zvavahera, 2015; Nuseir \& Madanat, 2015). Hence, loyalty is significant to build a long-term relationship between businesses and customers. As in the theory, there are many studies relating to the effect and relations among reference groups, customer satisfaction, and customer loyalty with various results (e.g Homburg \& Giering, 2001; Leverin \& Liljander, 2006; Caruana, 2002; Lau \& Phau, 2007; Ndubisi, 2007; Walsh, Heiner \& Maren, 2008; Karatepe, 2011; Rubio, Oubina \& Villasenor, 2014; Risa, 2016). In the previous studies, customer satisfaction is considered as the former of the loyalty in service (e.g Lam et al., 2004; Coelho \& Henseler, 2012; Belás \& Gabčová, 2016)

In terms of the Marketing sector, including marketing mix and relationship marketing, there are many studies on its effect on customer satisfaction and customer loyalty with different results (Marshall \& Rossman, 2011; Suthar, Lathangi, \& Pradhan, 2014). According to Rust, Zeithaml and Lemon (2000), the businesses own a high quantity of satisfied customers, and completely, product/ service structure and quality will be improved further because they put believes and trusts, pay more, and contribute to the profitability and the development of the businesses and, customer loyal will definitely come and develop. Significantly, businesses' brand loyalty from customers makes businesses reduce the product costs, attract new customers, enhance the organization's reputation (Bontis, Booker \& Serenko, 2007). Relating to customer loyalty process of businesses. There are numerous studies on the compositions of the marketing impacting to client fulfillment and customer loyalty such as the contribution of the supply chain to customers' loyalty towards businesses and its brands, the involvement of stakeholders as suppliers, manufacturers, distributors, and end customers to businesses' capability to do superior to gratify a customer (Poirier, 1990), on time products delivery (Cravens \& Piercy, 2007). Product pricing (Collins \& Parsa, 2006), customers' response (Cravens \& Piercy, 2007), promotion techniques (Mills, 2003; Jensen \& Jepsen, 2006; Hollensen, 2007), Productive management (Jerenz, 2008). And in other studies, customer satisfaction, customer loyalty, and organization initiatives of quality standards (Cravens \& Piercy, 2007; Li \& Green, 2010), and product quality (Bei \& Chiao, 2001; Caruana, 2002; Fullerton \& Taylor, 2002; Dimyati \& Subagio, 2016) have been proved on their relationships.

Research model and hypothesis

As above statements, the research model for the study is developed as follows

Figure of Proposed research model 


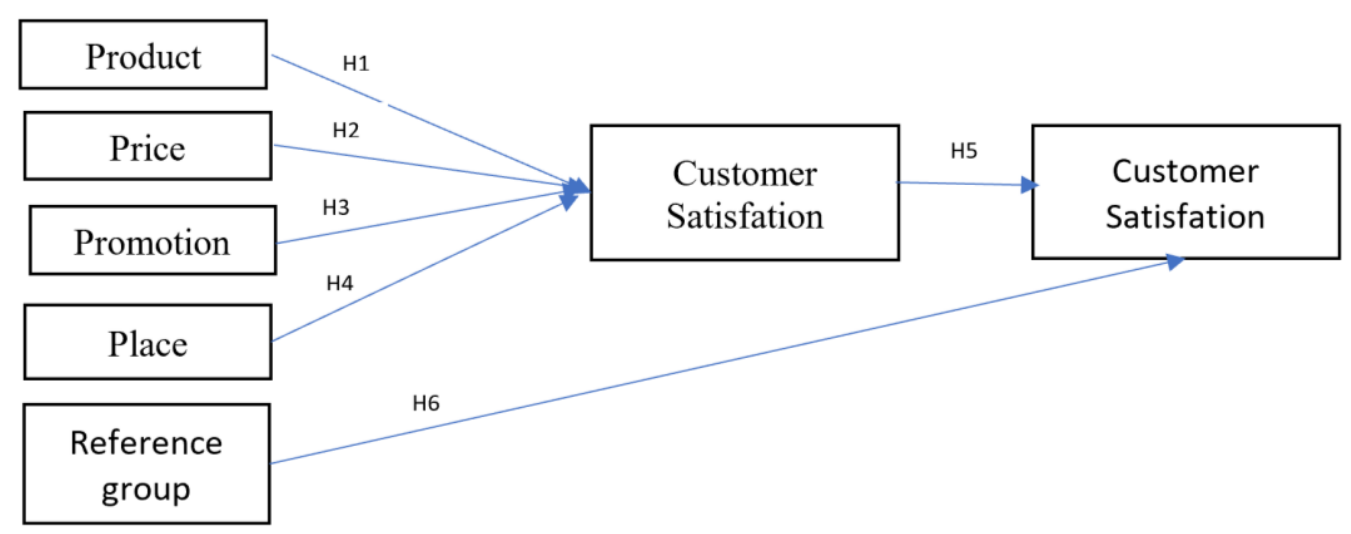

Hypotheses are established as follows

- H1: There is a positive correlation between products and customer satisfaction.

- $\mathrm{H} 2$ : There is a positive correlation between price and satisfaction.

- H3: There is a positive correlation between promotion and customer satisfaction.

- H4: There is a positive correlation between place and customer satisfaction.

- H5: A relationship exists between customer satisfaction and customer loyalty.

- H6: A relationship exists between reference groups and customer loyalty.

\section{Research Methodology}

The study employs 2 kinds of data - the secondary information and primary information with qualitative and quantitative study techniques through 2 phrases.

The first phase is done with qualitative research techniques with the secondary and primary data. Firstly, the related literature and theories have been explored in the published journals, books, and other sources like websites, businesses' reports, etc. Secondly, consultations with 6 academic researchers, 27 business owners, and 15 managers for exploration of the overview and current market/ business status, hidden issues, and measurement scales for the study have been done through the 5 interviews. In addition, group discussions and 3 in-depths planned interviews have been done with 30 random customers to increase a deep considerate of the measurement scales (observed variables) as a crosscheck for better outcomes.

The second phase is done with the quantitative research tool after achieving results from the qualitative method and the questionnaire is the key tool to collect data. The questionnaire content is adapted from previous studies as Poirier (1990); Rust, Zeithaml and Lemon (2000); Homburg and Giering (2001); Bei and Chiao (2001); Caruana (2002); Fullerton and Taylor (2002); Mills (2003); Lam et al. (2004); Leverin and Liljander (2006); Collins and Parsa (2006); Jensen and Jepsen (2006); Lau and Phau (2007); Ndubisi (2007); Bontis, Booker and Serenko (2007); Cravens and Piercy (2007); Hollensen (2007); Walsh (Heiner and Maren (2008); Jerenz (2008); Li and Green (2010); Karatepe (2011); Marshall and Rossman (2011); Coelho and Henseler (2012); Rubio, Oubina and Villasenor (2014); Suthar, Lathangi and Pradhan (2014); Belás and Gabčová (2016) Risa (2016); Dimyati and Subagio (2016). After establishing the questionnaire, before initiating out for the definite survey, the authors have 
completed pilot tests with 10 random customers to ensure directness and send response to progress the simplicity of the survey. As known, this study is the post-positivism rigor and Hair et al. (2010) defines the sample size should be as $\mathrm{N}=5$ *item (where item means observed variables) and Tabachnick \& Fidell (2001, 2007) confirms the sample size should be as $\mathrm{N}=8 *$ var +50 (where var means independence variables using in the regression model). Therefore, the study uses 200 surveyed questionnaires with the customers in milk product retail stores in Ho Chi Minh city. Also, it should be explained that the sampling technique in this study is the convenient technique. After all, the information is progressed with statistical methods as Cronbach's Alpha, EFA, T-Test, ANOVA, etc.

\section{Findings And Discussions}

\section{Results of demographic}

The table shows the ratio of male customers are at $38 \%$ and female customers at $62 \%$. This is consistent with the market and purchasing behavior and culture in Vietnam. As known, males often do not pay attention to the market service. Also, the age range is wide, however, most of the customers are over 50, accounting for 32\%. As for the employment, the respondents are mainly the pupils and students at a ratio of $40,5 \%$. Besides their income is mostly under 6 million at $64,5 \%$

Table 1: Result of demographic analysis

\begin{tabular}{|l|l|l|}
\hline & Frequency & Ratio (\%) \\
\hline Gender & & \\
\hline Maũ & 76 & 38.0 \\
\hline Age range & 124 & 62.0 \\
\hline Under 18 & & \\
\hline $18-35$ & 44 & 22.0 \\
\hline $36-50$ & 57 & 28.5 \\
\hline Above 50 & 35 & 17.5 \\
\hline Employment & 64 & 32.0 \\
\hline Governmental officer & & \\
\hline Business officer & 22 & 11.0 \\
\hline Self-employed & 17 & 8.5 \\
\hline Blue collared workers & 25 & 12.5 \\
\hline Housewives & 7 & 3.5 \\
\hline Retirement & 20 & 10.0 \\
\hline Pupils / students & 23 & 11.5 \\
\hline Others & 81 & 40.5 \\
\hline Income & & 5 \\
\hline Under VND 6 million/ month & 123 & 61.5 \\
\hline 6 - 8 million/ month & 49 & 24.5 \\
\hline 8 - 12 million/ month & 19 & 9.5 \\
\hline Above 12 million/ month & 9 & 4.5 \\
\hline
\end{tabular}

Source: Own (2021) 
The process to test the model will be gone with 2 key tools of Cronbach's Alpha and Exploratory Factor Analysis test. As analyzed, table 2 presents the descriptive statistics and the reliability coefficients of the studied variables the reliability of all the constructs used in this study are found acceptable to process and analyze in the next step.

Table 2: Reliability Coefficient and Descriptive Statistics

\begin{tabular}{|l|l|l|l|}
\hline & Cronbach's Alpha & Mean & Std deviation \\
\hline Product (PDC) & 0.867 & 3.62 & .764 \\
\hline Price (PRI) & 0.811 & 3.72 & .694 \\
\hline Promotion (PRO) & 0.813 & 3.88 & .647 \\
\hline Place (PLA) & 0.804 & 3.84 & .764 \\
\hline Satisfaction (STF) & 0.609 & 3.88 & .640 \\
\hline Reference Groups (REF) & 0.804 & 3.60 & .838 \\
\hline Loyalty (LYT) & 0.798 & 3.85 & .603 \\
\hline
\end{tabular}

Source: Own (2021)

The results of EFA analysis show all variables are appropriate and satisfactory as follows:

Table 3: Results of EFA analysis

\begin{tabular}{|l|l|l|l|l|}
\hline \multicolumn{5}{|l|}{ Component } \\
\cline { 2 - 5 } & 1 & 2 & 3 & 4 \\
\hline PDC1 & .864 & & & \\
\hline PDC2 & .862 & & & \\
\hline PDC3 & .863 & & & \\
\hline PDC4 & .760 & & & \\
\hline PRI1 & & .674 & & \\
\hline PRI2 & & .796 & & \\
\hline PRI3 & & .829 & & \\
\hline PRI4 & & .794 & & \\
\hline PRO1 & & & .692 & \\
\hline PRO2 & & & .811 & \\
\hline PRO3 & & & .809 & \\
\hline PRO4 & & & .840 & \\
\hline PLA1 & & & & .752 \\
\hline PLA2 & & & & .836 \\
\hline PLA3 & & & & .822 \\
\hline PLA4 & & & & .757 \\
\hline
\end{tabular}

Extraction Method: Principal Component Analysis.

Rotation Method: Varimax with Kaiser Normalization.

a. Rotation converged in 5 iterations.

Source: Own (2021)

As for the EFA results with factors affecting customer loyalty, The results of EFA analysis showed that 2 factors extracted at the eigenvalue at 1,559 and the variance extracted is $60.525 \%$ and the PRO is 0.717 . Therefore, they are appropriate, and the variance is satisfactory $>50 \%$.

Table 3: EFA results with factors affecting customer loyalty

\begin{tabular}{|l|l|l|}
\hline \multirow{2}{*}{} & \multicolumn{2}{|l|}{ Components } \\
\cline { 2 - 3 } & 1 & 2 \\
\hline REF3 & .809 & \\
\hline
\end{tabular}


Source: Own (2021)

\begin{tabular}{|l|l|l|}
\hline REF2 & .808 & \\
\hline REF4 & .732 & \\
\hline REF1 & .707 & \\
\hline STF1 & & .745 \\
\hline STF3 & & .648 \\
\hline STF2 & & .626 \\
\hline
\end{tabular}

Regarding the EFA result of variables affecting customer satisfaction, it shows that the observed variables of this scale are satisfactory for the next analysis.

Table 4: EFA results with factors affecting customer satisfaction.

Source: Own (2021)

\begin{tabular}{|l|l|}
\hline \multirow{2}{*}{} & Factors \\
\cline { 2 - 2 } & 1 \\
\hline STF1 & .779 \\
\hline STF3 & .761 \\
\hline STF2 & .711 \\
\hline
\end{tabular}

And for the EFA analysis results of the variables of customer loyalty, all of them are high, the lowest is variable LYT2 $=0.621$. Thus, the observed variables of this scale are satisfactory for the next analysis.

Table 5: EFA results with factors affecting customer loyalty.

\begin{tabular}{|l|l|}
\hline \multicolumn{1}{|c|}{} & Factors \\
\cline { 2 - 2 } & 1 \\
\hline LYT5 & .790 \\
\hline LYT6 & .787 \\
\hline LYT4 & .731 \\
\hline LYT1 & .701 \\
\hline LYT3 & .638 \\
\hline LYT2 & .621 \\
\hline
\end{tabular}

Extraction Method: Principal Component Analysis.

Rotation Method: Varimax with Kaiser Normalization.

a. Rotation converged in 3 iterations.

Source: Own (2021)

With the result of regression analysis, the table depicts the model has $R^{2}=0.613$ and adjusted $R^{2}=0.605$ and adjusted $R^{2}$ is smaller than $R^{2}$. Adjusted $R^{2}=0.605$ indicates the appropriateness of the model is $60.5 \%$. Also, the ANOVA analysis points out that $\mathrm{F}$ has a significance level (sig.) $=.000 \mathrm{~b}$, which proves that the research regression representation is consistent with the gathered data set, and the included variables are significant statistically significant with a $5 \%$ consequence level. Thus, the independent variables in the model are related to the dependent variable "Satisfaction". The regression results show that 4 important factors as Product, Product Price, Promotion, Place (Distribution channel) affecting customer satisfaction have linear relationships with customer satisfaction (Sig <0.05). Therefore, these 4 factors will be retained in the regression model. 
Table 5: Results of regression analysis

\begin{tabular}{|c|c|c|c|c|c|c|c|c|}
\hline \multirow{2}{*}{\multicolumn{2}{|c|}{ Model }} & \multicolumn{2}{|c|}{$\begin{array}{l}\text { Unstandardized } \\
\text { Coefficients }\end{array}$} & \multirow{2}{*}{$\begin{array}{l}\text { Standardized } \\
\text { Coefficients } \\
\text { Beta }\end{array}$} & \multirow{2}{*}{$\mathrm{t}$} & \multirow{2}{*}{ Sig. } & \multicolumn{2}{|c|}{$\begin{array}{l}\text { Collinearity } \\
\text { Statistics }\end{array}$} \\
\hline & & B & $\begin{array}{l}\text { Std. } \\
\text { Error }\end{array}$ & & & & Tolerance & VIF \\
\hline \multirow{5}{*}{1} & (Constant) & .112 & .231 & & .482 & .630 & & \\
\hline & PDC & .115 & .035 & .156 & 3.308 & .001 & .890 & 1.123 \\
\hline & PRO & .304 & .043 & .329 & 7.012 & .000 & .903 & 1.108 \\
\hline & PLA & .163 & .036 & .208 & 4.525 & .000 & .939 & 1.065 \\
\hline & PRI & .415 & .043 & .480 & 9.647 & .000 & .802 & 1.247 \\
\hline
\end{tabular}

Dependent Variable: STF

Source: Own (2021)

Model Summary ${ }^{b}$

\begin{tabular}{|l|l|l|l|l|l|}
\hline Model & $\mathrm{R}$ & $\mathrm{R}^{2}$ & Adjusted R & $\begin{array}{l}\text { Std. Error of } \\
\text { the Estimate }\end{array}$ & Durbin - Watson \\
\hline 1 & $.783^{a}$ & .613 & .605 & .301 & 2.093 \\
\hline
\end{tabular}

Source: Own (2021)

Table 6 states the results of multiple linear regression analysis of the model have $\mathrm{R}^{2}=$ 0.433 and adjusted $R^{2}=0.427$ and adjusted $R^{2}$ is smaller than $R^{2}$. Also, ANOVA analysis shows $\mathrm{F}$ has a significance level (sig.) $=.000 \mathrm{~b}$, which proves that the built-in regression model is consistent with the collected data, and the variables have statistically significant at a $5 \%$ significance level. Thus, all factors and variables are correlated. More of that, the regression results show that 2 crucial factors: Satisfaction, and reference groups have linear relationships with customer loyalty (Sig <0.05). Thus, these two factors will be retained in the regression model.

Table 6: Analysis linear regression models (loyalty)

\begin{tabular}{|l|l|l|l|l|l|l|l|l|}
\hline \multirow{2}{*}{ Model } & \multicolumn{2}{|l|}{$\begin{array}{l}\text { Unstandardized } \\
\text { Coefficients }\end{array}$} & $\begin{array}{l}\text { Standardized } \\
\text { Coefficients }\end{array}$ & \multirow{2}{*}{$\mathrm{t}$} & \multirow{2}{*}{ Sig. } & \multicolumn{2}{l|}{$\begin{array}{l}\text { Collinearity } \\
\text { Statistics }\end{array}$} \\
\cline { 3 - 10 } & B & Std. Error & Beta & & & Tolerance & VIF \\
\hline \multirow{3}{*}{1} & B Constant) & 1.364 & .208 & & 6.545 & .000 & & \\
\cline { 2 - 9 } & REF & .113 & .035 & .176 & 3.218 & .002 & .968 & 1.033 \\
\cline { 2 - 9 } & STF & .538 & .049 & .603 & 11.066 & .000 & .968 & 1.033 \\
\hline
\end{tabular}

Model Summary ${ }^{b}$

\begin{tabular}{|l|l|l|l|l|l|}
\hline Mode & $\mathrm{R}$ & $\mathrm{R}^{2}$ & Adjusted $\mathrm{R}^{2}$ & Std. Error of the Estimate & Durbin - Watson \\
\hline 1 & $.783^{a}$ & .433 & .427 & .323 & 1.892 \\
\hline
\end{tabular}

\section{Conclusions}

First, the regression results show that there are 4 important factors affecting customer satisfaction: Product, Price, Promotion, Place (Distribution channel) have linear relationships with customer satisfaction (Sig <0.05). Also, 2 crucial other factors: Satisfaction and reference group have linear relationships with customer loyalty $(\mathrm{Sig}<0.05)$. Throughout this study, the results recommend businesses in the dairy market should have concrete measurement scales to measure concepts relating to the development of customer satisfaction and customer loyalty. 
Secondly, the Board of Management or Directors of the related businesses as dairy corporations, retail shops' owners, and researchers gain deep understandings of factors affecting customer satisfaction and loyalty. Consequently, businesses will have suitable approaches to develop, achieve and measure customer satisfaction and customer loyalty by focusing on the relational marketing tools and strategies.

\section{References}

[1] Akroush, N. M. (2010). Transactional marketing and relationship marketing paradigms: A structural equation modelling approach. Int. J. Electronic Customer Relationship Management, $4(2), 125-160$.

[2] Aksoy, L. (2013). How do you measure what you can't define? The current state of loyalty measurement and management. Journal of Service Management, 24(4), 356-381.

[3] Aksu, A. (2006). Gap analysis in customer loyalty: A research in 5-star hotels in the Antalya region of Turkey. Qual. Quant., 40(2), 187-205.

[4] Alden, M. (2012). Dividend growth businesses with high switching costs. Dividend Monk. Available at http://dividendmonk.com/5-dividend-growth-businesses-with-high-switchingcosts/

[5] Allender, W. J. \& Richards, T. J. (2012). Brand loyalty and price promotion strategies: An empirical analysis. Journal of Retailing, 88(3), 323-342.

[6] American Marketing Association - AMA (2017). Definitions of Marketing. Available at https://www.ama.org/the-definition-of-marketing-what-is-marketing/

[7] Armstrong, G. \& Kotler, P. (2011). Marketing: An Introduction (10th Eds). Pearson Publishing.

[8] Balbanis, G., Reynolds, N., \& Simintiras, A. (2006). Bases of e-store loyalty: Perceived switching barriers and satisfaction. Journal of Business Research, 59(2), 214-224.

[9] Bandara, S.S.U. \& Wanninayake, W.M.C.B. (2012). The Impact of Closeness and the Profession of Reference Groups towards Brand Loyalty of Beer Products: A Study on Sri Lankan PerPDCective. Paper presented at the ICBI2012- Management and Marketing conference, pp. 78-88.

[10] Barnes, J. G. (2003). Establishing Meaningful Customer Relationships: Why some Companies and Brands Mean More to Their Customers. Managing Service Quality,13(3), 178-186.

[11] Bay, S., Petrizzi, R. \& Gill, P. (2008). The why of the buy: Consumer behavior and fashion marketing. New York: Fairchild Books.

[12] Bearden, W.O., Etzel, M.J., 1982. Reference group influence on product and brand purchase decisions. Journal of Consumer Research. 9(2), 183-194.

[13] Bei, L. T. \& Chiao,Y-C. (2001). An Integrated Model for The Effects of Perceived Product, Perceived Service Quality, and Perceived Price Fairness on Consumer Satisfaction and Loyalty. Journal of Consumer Satisfaction, Dissatisfaction and Complaining Behavior 14, 125 140.

[14] Belas, J. \& Gabčová, L. (2016). The relationship among customer satisfaction, loyalty and financial performance of commercial banks. E+M Ekonomie a Management, 19(1), 132-147.

[15] Bontis, N., Booker, L. \& Serenko, A. (2007). The Mediating Effect of Organizational Reputation on Customer Loyalty and Service Recommendation in the Banking Industry. Management Decision, 45(9), 1426-1445.

[16] Brunner, T., Stöcklin, M. \& Opwis, K. (2008). Satisfaction, image and loyalty: New versus experienced customers. European Journal of Marketing 42, 1095-1105.

[17] Caruana, A. (2002). Service loyalty: The effects of service quality and the mediating role of customer satisfaction. European Journal of Marketing, 36(7/8), 811-828. 
[18] Chang, C. H. \& Tu, C.Y. (2005). Exploring Store Image, Customer Satisfaction and Customer Loyalty Relationship: Evidence from Taiwanese Hypermarket Industry. Journal of American Academy of Business 7, 197-202.

[19] Chen-Yu, J. \& Hong, K-H. (2002). Antecedents and consequences of consumer satisfaction/dissatisfaction with the performance of apparel products at purchase and after consumption: A comparison of male and female South Korean consumers. International Journal of Consumer Studies 26, 117 - 127.

[20] Chigora, F. \& Zvavahera, P. (2015). Awareness completes brand loyalty: Reality of Zimbabwe Tourism Destination. Business and Management Horizons, 3(2), 60-69.

[21] Chung, M. (2021). In what scenario will the dairy industry grow in 2021? Available at https://vneconomy.vn/nganh-sua-nam-2021-se-tang-truong-theo-kich-ban-nao20210201141922071.htm

[22] Coelho, P. \& Henseler, J. (2012). Creating Customer Loyalty through Service Customization. European Journal of Marketing, 46(3/4), 331-356.

[23] Collins, M., \& Parsa, H. G. (2006). Pricing strategies to maximize revenues in the lodging industry. International Journal of HoPDCitality Management, 25(1), 91-107.

[24] Cravens, W. D. \& Piercy, N. (2007). Marketing Estratégico. Mcgraw Hill - Artmed.

[25] Dick, A. S. \& Basu, K. (1994), 'Customer loyalty: toward an integrated conceptual framework', Journal of the Academy of Marketing Science, 22(2), 99-113.

[26] Dimyati, M. \& Subagio, N. A. (2016). Impact of Service Quality, Price, and Brand on Loyalty with the mediation of Customer Satisfaction on Pos EkPDCres in East Java. Mediterranean Journal of Social Sciences, 7(4), 74-86.

[27] Dubrovski, D. (2001). The role of customer satisfaction in achieving business excellence. Total Quality Management, 12(7), 920-925.

[28] Flavian, C., Martinez, E. \& Polo, Y. (2001). Loyalty to grocery stores in the PDCanish market of the 1990s. Journal of Retailing and Consumer Services, 8(2), 85-93. 